\title{
The Model Regulation of Wawasan Nusantara as Indonesian Maritime Development Strategy Towards World Maritime Axis
}

\author{
Muh.Risnain* \\ International Law Dept, Faculty of Law \\ University of Mataram \\ Mataram, Indonesia \\ risnain82@gmail.com \\ Erlies Septiana Nurbani \\ International Law Dept, Faculty of Law \\ University of Mataram \\ Mataram, Indonesia \\ erlisseptiana@unram.ac.id
}

\author{
F Fatahullah \\ Law and Society Dept, Faculty of Law \\ University of Mataram \\ Mataram, Indonesia \\ fatahullah200284@gmail.com \\ R Rusnan \\ Constitutional Law Dept, Faculty of Law \\ University of Mataram \\ Mataram, Indonesia \\ rusnan74@yahoo.co.id
}

\begin{abstract}
The background of this research is based on the degradation of the values of the archipelago insight in the policy of security, socio-cultural, legal, and national economic defense. The Wawasan Nusantara has become a vision for the development of the nation and state which has been long instilled by Indonesia's founders. In addition, President Joko Widodo's vision of becoming a maritime country towards a world maritime axis must be supported by the enthusiasm to implement the concept of Wawasan Nusantara in all aspects of maritime policies. The purpose of this study is to find a model for regulating the Wawasan Nusantara as an Indonesian maritime development strategy towards a world maritime axis which has been designed in the Draft Law on Wawasan Nusantara. This research produced an important finding that conceptually the insight of the archipelago is a paradigm, the perspective of the Indonesian nation about itself which includes geography, politics, socio-culture, defense, security, economy, and environment. The relationship between Pancasila, the $\mathbf{1 9 4 5}$ Constitution of the Republic of Indonesia, and the archipelago insight is, Pancasila is an ideological foundation and basic norm for the birth of the archipelago insight. The Wawasan Nusantara is a legal principle that is the basis for the birth of written legal norms. It brought consequences that it is difficult to regulate Wawasan Nusantara in the form of a positive and operational legal norm. However, its norms and spirit have been accommodated in various laws and regulations of the maritime sector. Thus, Wawasan Nusantara doesn't need to be regulated in a special law.
\end{abstract}

Keywords: Model Law, Maritime State, Wawasan Nusantara.

\section{I.INTRODUCTION}

Post-reform era, the Wawasan Nusantara concept no longer familiar or even forgotten by Indonesian people. This concept is ideal for Indonesian to position themselves as big nations within international relations. (1) Governance arrangement policy especially in the relationship between central and local government tends to degrade the concept. As a national outlook, since the amendment of Constitution
1945 of the Republic of Indonesia, Wawasan Nusantara has become part of territorial concept then regulate especially on state territory in the Art. 25A Constitution 1945 of the Republic of Indonesia stated that "the unitary state of the Republic of Indonesia is an archipelagic state, the boundaries, and rights of whose territory shall be established by law". Indonesian recognition as archipelago state with "Nusantara" as the main feature for the constitutional foundation as archipelago insight territorial concept. The problem is, how to implement archipelago insight which is not only a geographical concept but also geopolitics and geostrategy (2).

However, the archipelago insight concept has challenges in its implementation in Indonesia. For example, regional autonomy degraded the archipelago insight concept by giving authority to the local government to manage the maritime area. The province government is given the authority to manage 24 miles of the maritime area from the coastline, and the city/district government is given the authority to manage 12 miles. This matter is an anomaly of regulation. On the one side, Indonesia embraces the unitary state and archipelago insight, however in its implementation autonomy concept as if the unitary state was not characterized by Nusantara (archipelago) which is a political, social, cultural, security and defense unity (3).

Other challenges of archipelago insights in its implementation are internal and external security disturbance. The internal issues are the separatist movements in Indonesia such as Aceh Free Movement, Free Papua Organization and the South Maluku Republic are a serious threat to the existence of archipelago insights. At the external level, the frequent occurrence of territorial violations by foreign ships and aircraft such as illegal fishing by foreign fishing boats and airspace violations such as the F-18 Hawk case in Bawean in 2003 is clear evidence of the weakening insight of the archipelago in managing the country (4). 
President Joko Widodo launched Indonesia's maritime development program as one of the excellent programs to achieve the goal of making Indonesia the world's maritime axis. However, this program will not be achieved if it does not depart from the concept of archipelago insight as a national perspective in the development of the maritime world. The concept of archipelago insight, which calls for a unified perspective on geography, geopolitics, and geostrategic, geo-security, must be able to realize the vision of a maritime state launched by President Joko Widodo. However, the vision of a maritime state may not be achieved if the archipelago is not used as the basis for policymaking in the maritime sector.

Wawasan Nusantara which is defined as the Indonesian national outlook, how Indonesian see themselves and their environment according to Pancasila as state ideology and Constitution 1945, which inspirit state administration process to achieve national goals (5).

\section{II.METHODS}

In this study, using library research methods or library research with data collection methods obtained from various sources of review articles to produce data in the form of secondary data. This type of research library research is closely related to the collection of library data obtained from various library information, one of which is scientific journals (Syaodih et al., 2009). This research focuses on descriptive analysis by describing the data then analyzed and discussed so that the data obtained can be studied clearly (Baharsyah \& Admoko, 2020).

The data source in this study is in the form of secondary data. Secondary data is data from previous research results which are summarized and converted into a form of research essence which later can be used by subsequent researchers as a new form of related research.

\section{III.RESULT AND DISCUSSION}

\section{A. Findings}

- Considerations on Establishment of Wawasan Nusantara (Archipelago Insight) Draft Law: Between Ideology and Legal Needs

Since 2015, national political legislation making Wawasan Nusantara part of the draft law which will become binding norms and law. The political legislation willing is making Wawasan Nusantara which is viewed as a paradigm, how Indonesian see themselves which included geographical, political, social-cultural, state and defense, economy, and environment to be a positive norm [7]

The draft law intended archipelago insight to be positive, even though the Wawasan Nusantara perspective put it as a paradigm.[8] In this perspective, archipelago insight is considered as a legal principle that founded the birth of geographical, political, social, and culture, security, defense, economic, and environmental legislations. The further question is it possible for something which already considered a legal principle then regulate in a legal norm that is more operational in the form of laws?
To answer the above question, I cited the Wawasan Nusantara Draft Law considerations. The first consideration was, the form of the unitary state of the Republic of Indonesia with human and natural resources including marine area as the biggest part of Indonesia territory has the position and strategical value in all aspect of Indonesian people. Secondly, in principle, all free nations have their national outlook on the essence of their existence, also how they manage their social life to avoid loss of direction in the middle of international relations. The third consideration was. As Nusantara state, Indonesia has its national outlook in the form of Wawasan Nusantara which is sourced by Pancasila and Constitution 1945 of the Republic of Indonesia. And finally, the Archipelago's insight is currently experiencing a setback that has contributed to the multidimensional crisis in the life of the nation and state. Thus, with the spirit of reform that calls for the realization of democratization, protection of human rights, people's economy, regional autonomy, fair management of natural resources, diversity, and local wisdom. Archipelagic insight needs to be updated and contained in legal products that have binding power in the conduct of social, national, and state life.

\section{B. Discussion}

- Relation between Pancasila (Indonesia State Ideology) and Wawasan Nusantara

It is interesting to study the relation between Pancasila and archipelago insight within Wawasan Nusantara Draft Law, related to the laws and regulations [9]. Wawasan Nusantara Draft Law which has been proposed by the house of a representative not only regulate Wawasan Nusantara but also regulating Pancasila. The idea of regulating Pancasila in the draft law according to Art. 3 Wawasan Nusantara Draft Law put Pancasila as Indonesia state ideology. Explanation of draft law stated that state ideology means the collection of values, ideas, purposes, guidance, and Indonesia state administration method. The draft law also put Pancasila as open-ideology. Open means Pancasila can obtain new ideas to advance and to develop the state.

Realizing Pancasila as an open ideology, Wawasan Nusantara's draft law want Pancasila civilization through civic education subject in formal, informal, and non-formal education institutes and also through the political and social organization. Aims of civilization are to elevate knowledge, understanding, awareness, and practices of the Pancasila values. Further regulation in the draft law mentioned that Pancasila civilization will not use as requirements, method of appraisal and/or selection of public officials or as a requirement to get immigration document, resident document or any other official documents. Pancasila civilization held by putting forwards inspiration, innovative and facilitative methods.

Therefore, the relation between Pancasila, Constitution 1945 of the Republic of Indonesia, and Wawasan Nusantara are, Pancasila is an ideology foundation for the birth of Wawasan Nusantara. Pancasila is the highest source of law in the Indonesian legal system, meanwhile, the Constitution 1945 of the Republic of Indonesia is the highest-written source of law. Thus, Wawasan Nusantara is a legal 
foundation or legal principle which becomes the basis of written laws.

Wawasan Nusantara which put as Indonesian national outlook about themselves and their environment according to Pancasila as state ideology and Constitution 1945 of the Republic of Indonesia, which inspirit of state administration to achieve national goals.

The definition then put Wawasan Nusantara as the principle of state administration which functions as guidance, motivation, and direction in determining action, decision, the policy of state officials for all of Indonesian people life within society, nation and state according to every Silas of Pancasila.

As a national outlook, the scope of Wawasan Nusantara within Indonesian society was mentioned in the draft law, namely: Wawasan Nusantara in the field of law, Wawasan Nusantara in the field of politics and constitution, Wawasan Nusantara in the field of economy, Wawasan Nusantara in the field of natural and ocean resources management, Wawasan Nusantara in the field of social and culture and finally Wawasan Nusantara in the field of state defense.

Wawasan Nusantara aspects above show that conceptually Wawasan Nusantara considered as territorial outlook related to state defense, especially in the maritime area. Meaning extensification affects other fields for example law, politics and state administration, economy, natural and ocean resources, and social culture.

Archipelago insights meaning extensification have two sides that influence each other. First of all, archipelago insights only focus on state defense, security, and ocean resources. This focus would not able to cope all state problems which become more complex within dynamic international relation, Indonesian people should more pay attention to the dynamic international relations which occurs within international organizations. Secondly, the expanded concept of archipelago insights makes its implementations blur especially in the field of maritime defense and security.

\section{IV.CONCLUSION}

The regulation of archipelago insight as a strategy for Indonesia's maritime development towards a world maritime axis which has been regulated in the Draft Law on Archipelagic Insights has been regulated in various laws and regulations in the maritime sector, especially Law Number 17 of 1985 concerning the Ratification of UNCLOS 1982, Law Number 6 of 1996 concerning Indonesian Waters, Law Number 43 of 2008 concerning the territory of the country and Law Number 32 of 2014 concerning Maritime Affairs. The regulation of the archipelago insight in a separate law as implemented in the current national legislation program is not relevant for regulating the archipelago insight as a legal principle.

\section{REFERENCES}

[1] Sekretariat Pangkolnas, Paparan tentang Wawasan Nusantara (Pengakuan Perjuangan dan Implementasinya), Departemen Pertahanan dan Keamanan RI, Jakarta, 1982

[2] Atje Misbach Muhjidin, Status Hukum Perairan Kepulauan Indonesia dan Hak Lintas Kapal asing, Alumni, Bandung, 1993.

[3] Mochtar Kusumaatmadja, Konsepsi Hukum Negara Nusantara pada Konferensi Hukum Laut 1982, Alumni, Bandung, 2003

[4] M Budiarto, Wawasan Nusantara dalam Peraturan Perundangundangan Negara Republic Indonesia, Ghalia Indonesia, Jakarta, 1980 .

[5] Lembaga Pertahanan Nasional, Wawasan Nusantara : Naskah sementara, Lemhanas, Jakarta, 2000

[6] Wan Usman,Wawasan Nusantara, Makalah dalam Lokakarya Wasantara dan Tannas di Lemhannas pada bulan Januari tahun 2000.

[7] Toto Pandoyo, Wawasan Nusantara dan Implementasinya dalam UUD 1945 serta pembangunan nasional, Rineka Cipta, Bandung, 1994

[8] Dino Patti Djalal, The Geopolitics of Indoenesia's maritime territorial policy, CSIS, Jakarta, 1996.

[9] Soetandyo Wignjosoebroto, Hukum : Konsep dan Metode, Setara Press, Malang, 2013.

[10] Baharsyah, A. I., \& Admoko, S. (2020). Analisis Kemampuan Argumentasi Ilmiah Siswa Berbasis Pola Toulmins Argument Pattern (TAP) Menggunakan Model Argument Driven Inquiry dan Diskusi pada Pembelajaran Fisika SMA. Inovasi Pendidikan Fisika, 9(3).

[11] Syaodih, Sukmadinata, \& Nana. (2009). Pengembangan Kurikulum:Teori dan Praktek. In Journal of Chemical Information and Modeling. 